\title{
Magmatic origin and petrogenesis characterization of syenite rock from Pakkanadu alkaline complex, Southern Granulite Terrain, India: Implication on emplacement and petrogenetic history
}

\author{
P. Gangatharan* \\ Department of Geology, Periyar University, Salem - 636011 (Tamil Nadu), India \\ K. Anbarasu \\ Department of Geology, Periyar University, Salem - 636011 (Tamil Nadu), India \\ M. Satyanarayanan \\ National Geophysical Research Institute, Hyderabad - 500007 (Telangana), India
}

*Corresponding author. Email: gangatharangeo@gmail.com

\section{Article Info}

https://doi.org/10.31018/

jans.v13i4.2919

Received: August 16, 2021

Revised: October 24, 2021

Accepted: October 28, 2021

\section{How to Cite}

Gangatharan, P. et al. (2021). Magmatic origin and petrogenesis characterization of syenite rock from Pakkanadu alkaline complex, Southern Granulite Terrain, India: Implication on emplacement and petrogenetic history. Journal of Applied and Natural Science, 13(4), 1214 - 1224. https://doi.org/10.31018/jans.v13i4.2919

\begin{abstract}
The present study mainly focused on understanding the magmatic origin and petrogenesis characterization based on the Petrography, major, trace and Rare Earth Element (REE) signatures in the alkaline syenite from Pakkanadu alkaline carbonatite complex. The alkaline plutons from South Indian granulite terrain are intruded along with Archaean epidote-hornblende gneisses. The study area was carbonatite complexes of Tamil Nadu and is characterized by a group of rock associations Carbonatite-Syenite-Pyroxenite - Dunite. From Harker various patterns Pakkanadu alkaline complex syenite showed increasing trends of $\mathrm{SiO}_{2}, \mathrm{Al}_{2} \mathrm{O}_{3}, \mathrm{Na}_{2} \mathrm{O}+\mathrm{K}_{2} \mathrm{O}$ opposite to decreasing order of $\mathrm{CaO}, \mathrm{Fe}_{2} \mathrm{O}_{3}, \mathrm{MgO}, \mathrm{TiO}_{2}, \mathrm{P}_{2} \mathrm{O}_{5}$ and $\mathrm{MnO}$ trend, suggest fractionation of clinopyroxene, hornblende, sphene, apatite and oxide minerals and feldspar that ruled the fractionation. The concentration of trace elements enriched in Large lon lithophile elements (LILE) (Ba, Sr, and Rb) elements and High Field Strength Elements (HFSEs) indicated that the dyke intrusion by differentiation of magma from a mantle source. Rare earth element (REE) distribution of Light rare earth element (LREE) enriched and High rare earth element (HREE) depleted pattern show strongly fractionated pattern with moderate Eu anomalies. Plots of tectonic discrimination diagrams of Pakkanadu samples fall in the field of syn-COLG field to the VAG syn- COLG field. For the first time, this type of study was carried out in the study region in a detailed manner. The present study significantly exposed the petrography, petrogenesis and magmatic origin process in the Pakkanadu alkaline carbonatite complex.
\end{abstract}

Keywords: Alkaline Syenite, Pakkanadu Complex, Southern Granulite Terrane, Tectonic setting

\section{INTRODUCTION}

In Southern India, Salem and Dharmapuri districts of Tamil Nadu is a large number of Proterozoic syenite from the Alkaline-Carbonate-Ultramafic Complex of Pakkanadu, emplaced within the Precambrian granulite terranes on North East -South West direction (Gopalakrishnan 1996; Gopalakrishnan 1993; Gopalakrishanan and Ganesam 1992; Gopalakrishnan et al., 2002; Jeyabalan et al., 2015; Srinivas et al., 2011; Gangatharan and Anbarasu 2020 a, b). Tectonically, these alkaline igneous rocks are associated with continental rift valleys or divergent continental margins, oceanic and continental intraplate settings, and subduction zone magmatism (Fitton and Upton, 1987; Woolley, 1987; Burke et al., 2003, 2008; Leelanandam et al., 2006; Vijaya Kumar et al., 2007; Upadhyay, 2008; Woolley and Kjarsgaard, 2008; Ashwal et al., 2016; Ackerman et al., 2017; Ranjan et al., 2018). Their special geochemical signatures correlated with specific tectonic associations serve as an important tool for understanding mantle and crustal processes and their geodynamic manifestations (Santosh et al., 1989; Natarajan et al., 1994; Kumar et al., 1998; Upadhyay et al., 2006a, b; Upadhyay,2008; Mukhopadhyay et al., 2011; Renjith et al., 2014; Chakrabarty et al., 2016; 
Hippe et al., 2016; Ackerman et al., 2017; Das et al., 2019; Ranjan et al., 2018; Schleicher, H. 2019; Krishnamurthy, 2019; Paul et al., 2020). Geologically Pakkanadu Alkaline Carbonatite complex (PACC) ranging in Neo-Proterozoic age is distributed in a region of $150 \mathrm{~km}^{2}$ occurring $60 \mathrm{~km} \mathrm{SW}$ of the Samalpatti pluton. Profound crustal breaks (stitch/shear zones) framed during late Archaean to Proterozoic age have been barged in via Carbonatite Alkaline complexes. The Pakkanadu Alkaline Complex (PACC) is metamorphosed as shown by the development of large scale deformational structures (Miyazaki et al., 1999; Pandit et al., 1998; Schleicher et al., 1998; Pandit et al., 2002; Moller et al., 2001). Lithologies of this complex includes intrusive syenite, and discontinuous bodies of carbonatite associated with pyroxenite rocks. Structurally this alkaline complex has been intruded into migmatite gneisses, Hornblende biotite gneiss and amphibolite. Past workers have depicted the general geology and emplacement history of the Pakkanadu alkaline syenite complex (Gopalakrishnan 1996; Gopalakrishnan 1993; Gopalakrishanan and Ganesam 1992; Gopalakrishnan et al., 2002; Srinivas et al., 2011, Jeyabalan et al., 2015; Gangatharan and Anbarasu 2020 a, b). The present study reports the field occurrence, textural properties and geochemical signatures of alkaline syenite intrusion emplaced into a Pakkanadu alkaline Carbonatite complex. Further, the study demonstrates the major process involved in forming alkaline syenite plutons with the help of textural, major, trace and rare earth elements concentration and structural signatures in this complex.

\section{MATERIALS AND METHODS}

\section{Study area}

The present study focused on syenite intrusive bodies exposed in and around of Pakkanadu complex of

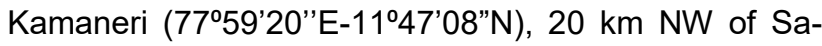
lem, on the road connecting Omalur - Mecheri, in the Salem district, Tamil Nadu. The syenite pluton occupies about $1 \mathrm{Sq}$. $\mathrm{Km}$ is composed of medium to coarsegrained K-feldspar and plagioclase observed with the help of hand lens. The smaller syenite pluton in Chindamaniyur and Semmandapatty, located $13 \mathrm{~km}$ East of Kamaneri pluton, was exposed in the $\mathrm{N}-\mathrm{S}$ direction (Fig.1). The varying width of pegmatite veins crosses within the syenite body results in the culmination of magmatic activity. Outcrop of pyroxenite was noticed and syenite composition with distinctive porphyritic structure was also noticed across the syenite body. A magmatic flow foliation is available throughout the syenite body, marked and recorded mainly by the shape alignment of K-feldspars (Fig.2).

\section{Analytical methods}

A detailed field study was carried out by using a toposheet (58 E/13) published by the Geological Survey of India. The sampling stations were marked by geographical coordinates using global position system (GPS) (Model: GARMIN 76 CSx). The fresh rock samples were collected from the ideal field exposure for laboratory study. The structural features and field relationship of the alkaline outcrop was studied in the field itself. The collected rock samples were processed for

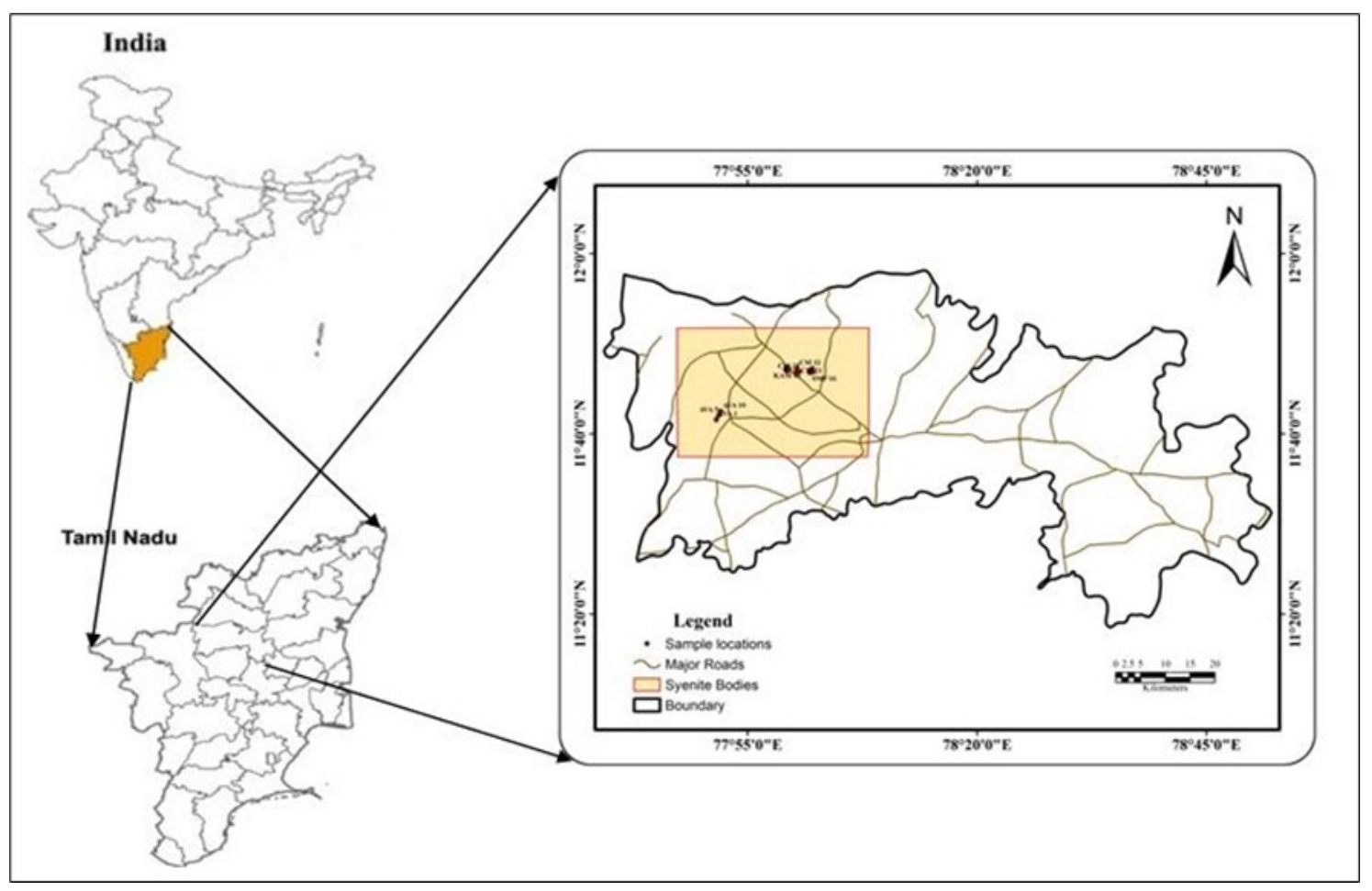

Fig. 1. Location map of the study area 
thin section preparation and the petrographic study examined by the petrological microscope LEICA-Model DM 2700P, in Department of Geology, Periyar University, Salem, Tamilnadu. For the petrographic textural study, seventeen samples for whole-rock geochemistry were selected using a standard procedure (Satyanarayanan et al., 2014). Major trace and REE analysis were carried out in National Geophysical Research Institute (NGRI), Hyderabad. The major oxides were analyzed by X-ray fluorescence spectrometer (Philips Magi X PRO mode PW 2440). Trace and REE analysis of whole-rock was done by ICP-MS (Perkin Elmer SCIEX, Model ELAN ${ }^{\circledR}$ DRC-II ICP - Mass Spectrometer).

\section{RESULTS AND DISCUSSION}

\section{Petrography}

The syenite rock from Pakkanadu alkaline complex showed heterogenetic, leucocratic to melanocratic appearance and medium to very coarse-grained pegmatite phase minerals composed mainly of K-feldspar, plagioclase followed by clinopyroxene (aegirine - augite), amphibole with minor accessory of biotite, euhedral titanite, sphene and opaque mineral. The thin section showed that minerals were euhedral to subhedral crystals arranged equally and showed holocrystalline nature that revealed hypidiomorphic texture. Alkali feldspar showed a wide range of complex exsolution and replacement textures. These minerals were easily identified by their typical polysynthetic and simple twin, and cross-hatched twining represented and was common in microcline. Some sections of feldspar minerals had inclusions by irregular intergrowths and cryptoperthitic minerals identified in syenite rock intrusion, indicating early-stage exsolution. Feldspar minerals showed intense fractures or cracks indicating solid-state deformation (Fig.3).

\section{Geochemistry: \\ Major oxides}

The major oxides analyses and trace elements of the representative samples from Pakkanadu alkaline complex results are given in the Table (1 and 2). The intrusive rocks from the pluton had a range of silica contents, from approximately 60 to $65 \%$. The rocks were alkali rich $\left(\mathrm{Na}_{2} \mathrm{O}+\mathrm{K}_{2} \mathrm{O}=8.66-13.65 \%\right)$ and the plot in the syenite compositional field in the total alkalis versus silica diagram clearly showed that the plots for all investigated syenite rocks fall in the alkaline field as per Middlemost (1994) (Fig. 4). Generally, Syenite rock was clearly pottasic in nature with $\mathrm{K}_{2} \mathrm{O}>\mathrm{Na}_{2} \mathrm{O}$. The total alkali $\left(\mathrm{Na}_{2} \mathrm{O}+\mathrm{K}_{2} \mathrm{O}\right)$ vs $\mathrm{SiO}_{2}$ (Fig. 5) obviously illustrate that the plots for all investigated syenite rocks

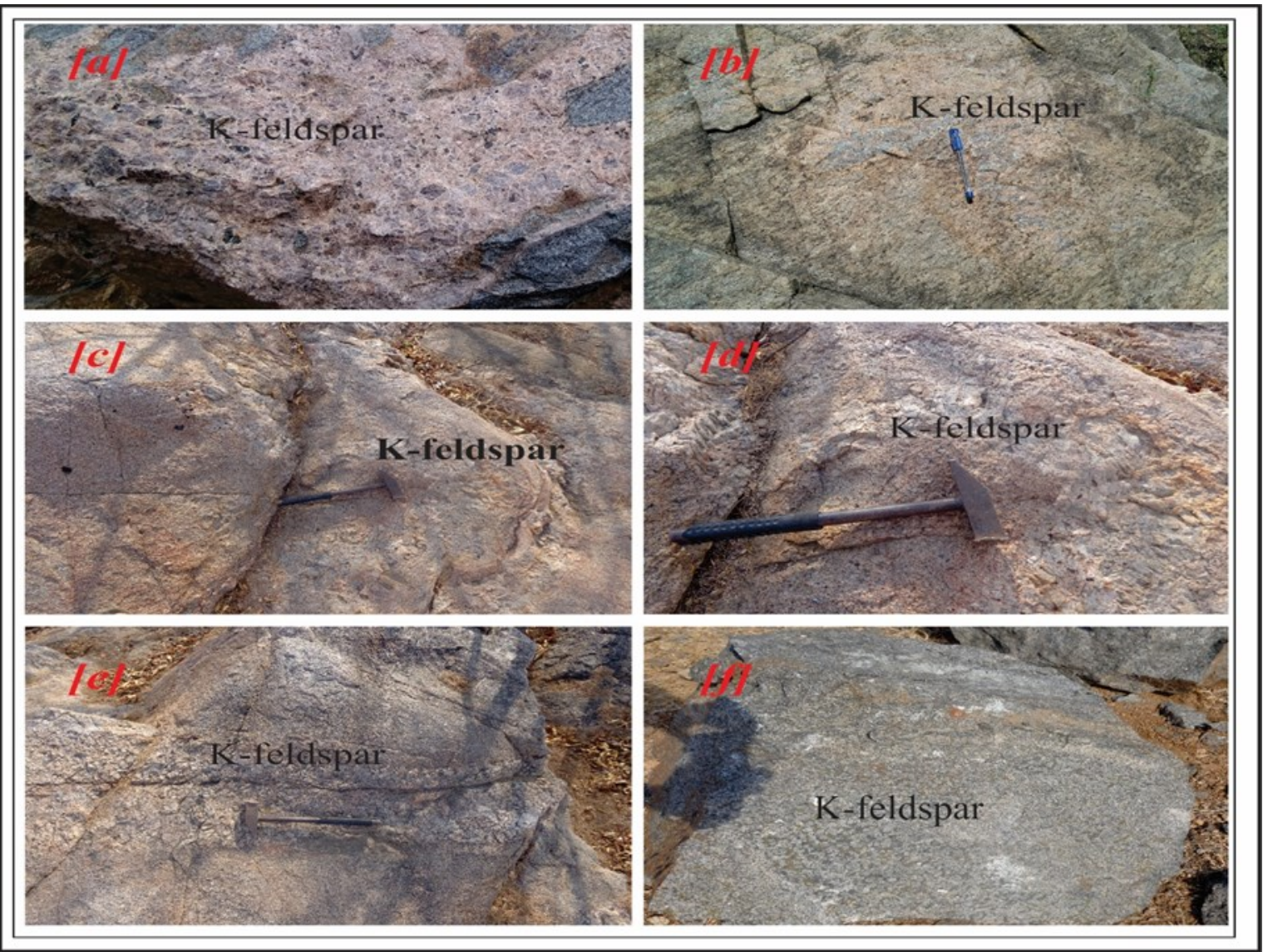

Fig. 2. (a-f). Field photographs of lithology from Pakkanadu alkaline syenite complex 

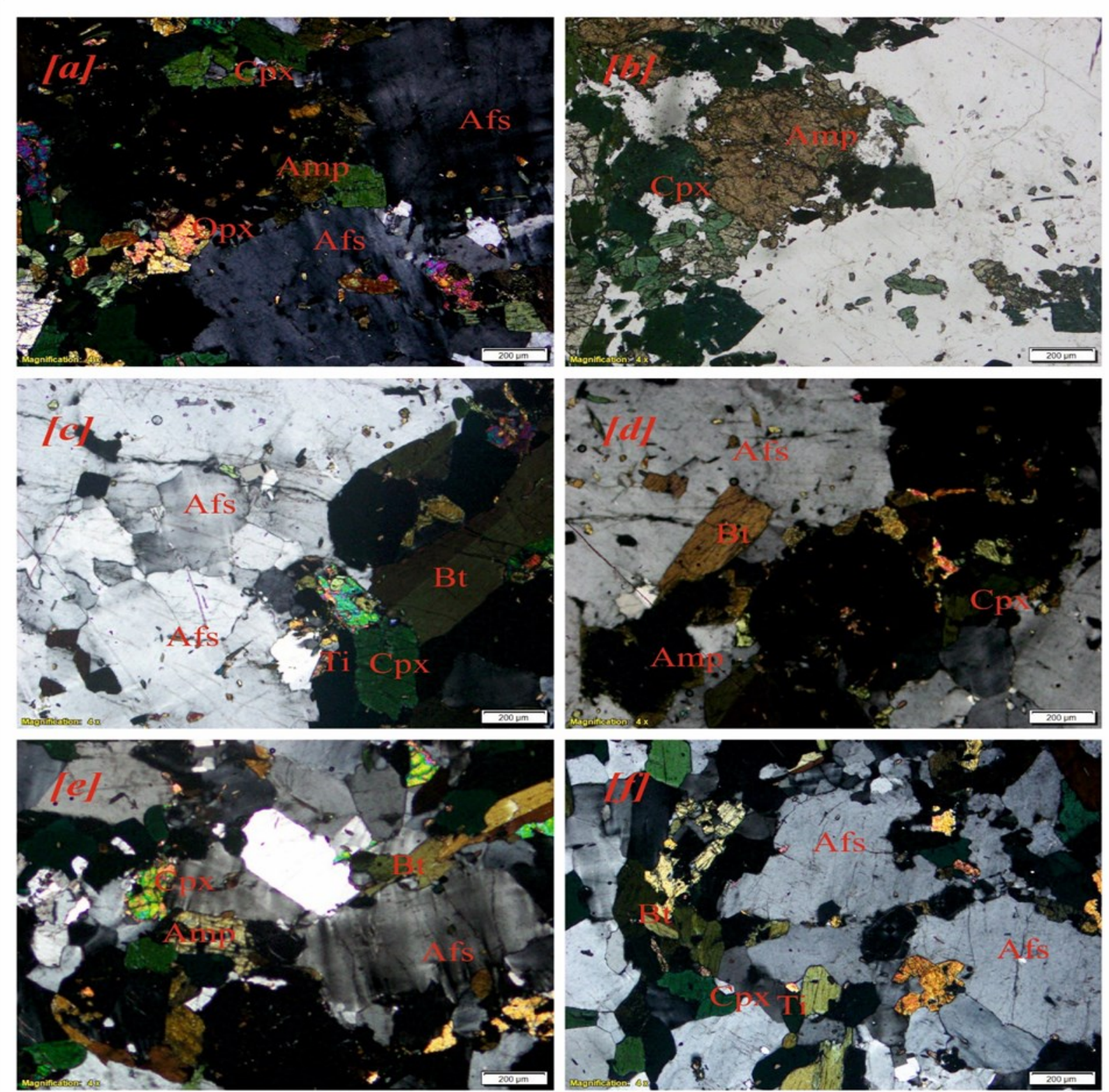

Fig. 3. Photomicrograph of Pakkanadu alkaline syenite a-f shows K-feldspar, plagioclase, clinopyroxene (aegirine - augite), amphibole and accessory of biotite, euhedral titanite, sphene and opaque mineral are euhedral to subhedral crystals arranged equally shows holocrystalline nature hypidiomorphic texture.

fall in the field of 'alkaline' series nature. The Harker variation diagrams demonstrated the syenite behaviour when they are plots against $\mathrm{SiO}_{2}$ (Fig. 6). Major oxides concentration showed clear trends of decreasing with increasing against silicate oxides $\mathrm{Al}_{2} \mathrm{O}_{3}, \mathrm{~K}_{2} \mathrm{O}, \mathrm{CaO}$, $\mathrm{Fe}_{2} \mathrm{O}_{3}, \mathrm{MgO}, \mathrm{Na}_{2} \mathrm{O}, \mathrm{TiO}_{2}, \mathrm{P}_{2} \mathrm{O}_{5}$ and $\mathrm{MnO}$ contents. These major elements against the $\mathrm{SiO}_{2}$ trend are generally moderately smooth, implying that the main process involves crystal fractionation results of magmatic evolution. Similar observations were noticed in log $\mathrm{CaO} /\left(\mathrm{Na}_{2} \mathrm{O}+\mathrm{K}_{2} \mathrm{O}\right)$ vs. $\mathrm{SiO}_{2}$ diagram (Fig.7) wherein all the samples were clustered with alkaline series, which indicates that the study area lithological composition closely belongs to alkaline nature. In the Alkali Iron
Magnesium (AFM) ternary diagram (Fig.8), all the samples clustered with Calc- Alkaline series indicate that the Pakkanadu alkaline lithological complex belongs to plutonic origin and rocks are formed by the slow cooling process during liquid to solid state (Rollinson 1993; Rao and Narayana 2002; Miyazaki et al., 2003; Miyazaki and Santosh 2005; Paul et al., 2020).

\section{Trace elements}

Trace elements distribution in primitive mantle normalised spider diagram as proposed by Kerrich and Wymann (1997) The samples are enriched in large ion lithophile elements (LILEs) such as $\mathrm{Sr}, \mathrm{Ba}$ and $\mathrm{Rb}$, High Field Strength Elements (HFSEs) such as $\mathrm{Y}, \mathrm{Nb}, \mathrm{Zr}$, 


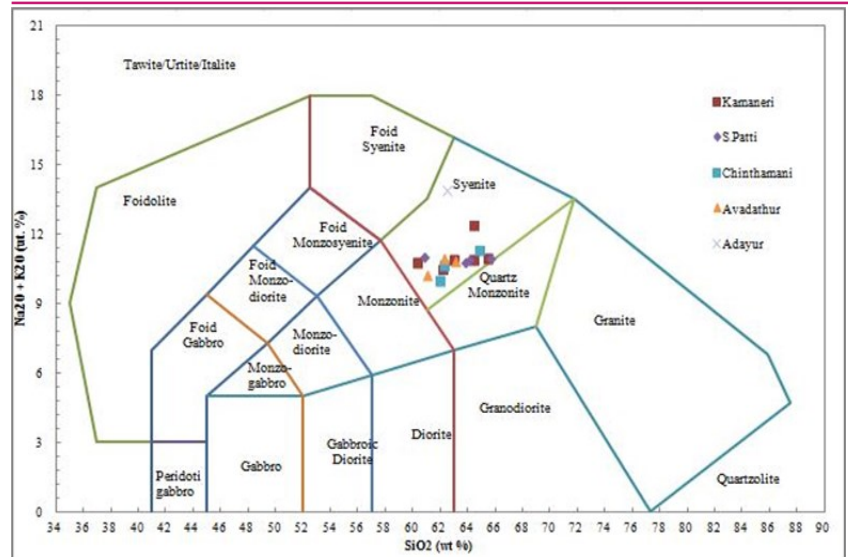

Fig. 4. Diagram of (TAS) Total Alkali vs Silica) (after Middlemost, 1994)

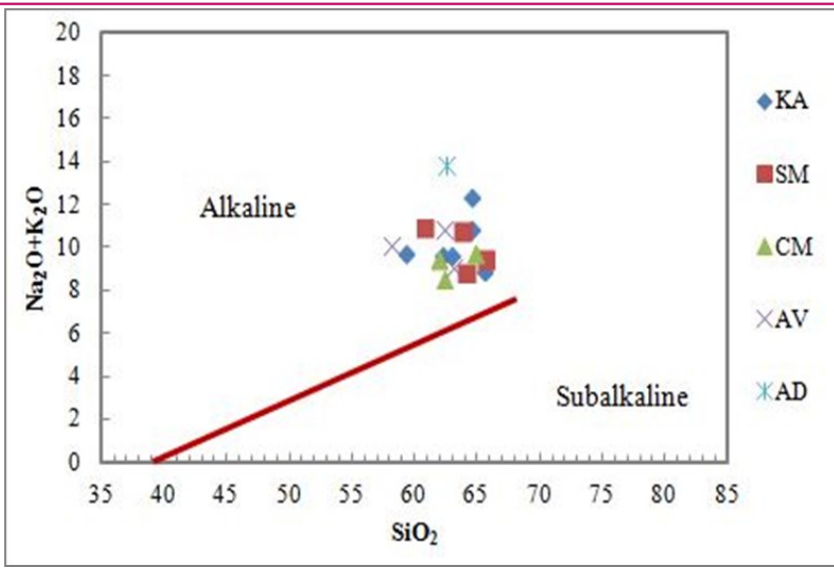

Fig. 5. Plots of $\left(\mathrm{Na}_{2} \mathrm{O}+\mathrm{K}_{2} \mathrm{O}\right)$ vs $\mathrm{SiO} 2$ (after Irvine and Baragar 1971).

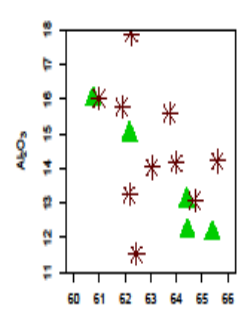

$\mathrm{SO}_{2}$

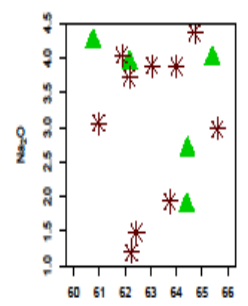

$80_{2}$

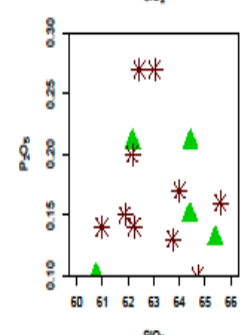

Multiple plot of $\mathrm{SiO}_{2}$ vs. $\mathrm{Al}_{2} \mathrm{O}_{3}, \mathrm{MgO}, \mathrm{CaO}, \mathrm{Na}_{2} \mathrm{O}, \mathrm{K}_{2} \mathrm{O}, \mathrm{TiO}_{2}, \mathrm{P}_{2} \mathrm{O}_{5}$

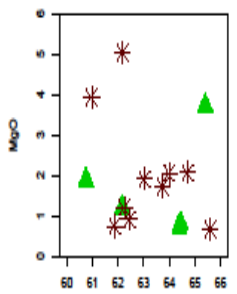

sio,

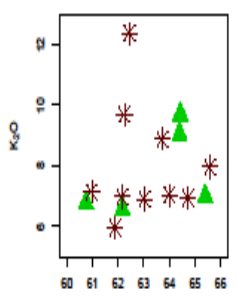

sio,

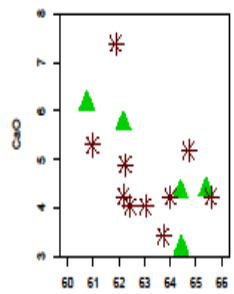

$\mathrm{SO}_{2}$

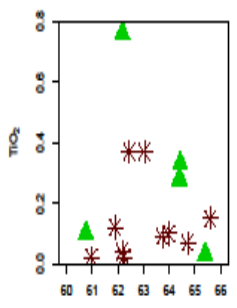

$80_{2}$

Fig.6. Harker variation diagram of Pakkanadu alkaline Kamaneri Syenite complex

$\mathrm{Ta}, \mathrm{Hf}$ and, Th, and depletion of Ferromagnesium and Transitional Elements (FTEs) such as $\mathrm{V}, \mathrm{Cr}, \mathrm{Co}, \mathrm{Ni}$, $\mathrm{Cu}, \mathrm{Zn}$ except $\mathrm{Pb}$ (Fig.9). The high concentration of enriched LILE ( $\mathrm{Ba}, \mathrm{Sr}$, and $\mathrm{Rb}$ ) elements indicates that the dyke intrusion is derived from magma differentiation from mantle sources. The high $\mathrm{Ba}$ and $\mathrm{Sr}$ anomaly concentration infer that lithological characterization of Pakkanadu alkaline complex is mainly controlled by plagioclase fractionation and followed by a small range of partial melting. The depletion of ferromagnesian and transitional elements such as $\mathrm{V}, \mathrm{Cr}, \mathrm{Co}, \mathrm{Ni}, \mathrm{Cu}$, and $\mathrm{Zn}$ from the primitive mantle normalized values reveal that mafic minerals deficient, feldspar ruled fractionation as also reported earlier (Taylor et al., 1967; Rollinson 1993; Schleicher et al., 1998; Pandit et al., 2002; Upadhyay et al., 2006c; Srinivas et al., 2011; Santosh et al., 2014; Paul et al., 2020).

\section{Rare earth elements}

The Rare earth element concentrations of the syenite rock are demonstrated in chondrite-normalized diagrams using the chondrite values of McDonough and Sun (1995) (Fig. 10). The Rare Earth Element pattern showed overall low to moderate of the $\Sigma R E E$ contents from alkaline syenite rock values ranges from 25.77388.49 mean value 160.94 (Table 3 ). $\Sigma$ LREE values 
range from 22.20-35.5, mean value 145.70, $\Sigma$ HREE values range from $3.20-36.03$, mean value 15.36 . The present record on the REE of the studied syenite indicated that all samples are strongly enriched in LREE $(\mathrm{La} / \mathrm{Sm})_{\mathrm{n}}$ (values ranged from 2.11-12.02, mean value 6.74), and depleted in HREE $(\mathrm{Tb} / \mathrm{Yb})_{n}$ (values ranged from $0.15-0.49$, mean value 0.33), for Pakkanadu complex alkaline syenite, respectively. This suggests

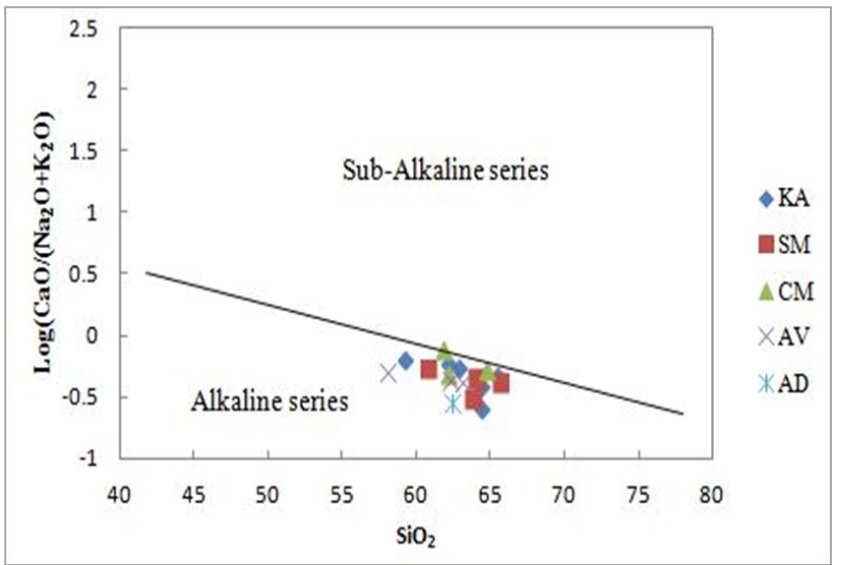

Fig.7. $\mathrm{Log}\left(\mathrm{CaO} / \mathrm{Na}_{2} \mathrm{O}+\mathrm{K}_{2} \mathrm{O}\right)$ vs $\mathrm{SiO}_{2}$ of Syenite rock

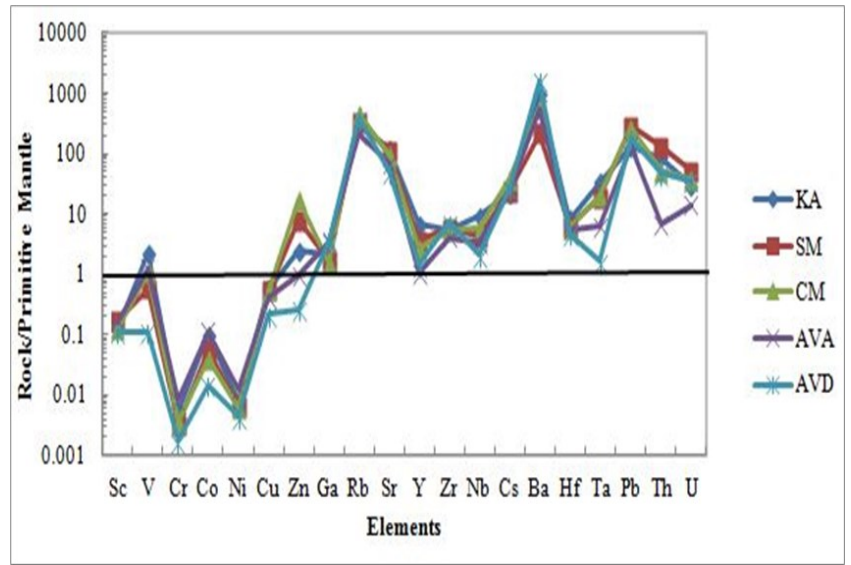

Fig. 9. Primordial Mantle normalized multielement spidergram of Pakkanadu alkaline Kamaneri Syenite complex (Kerrich and Wymann, 1997).

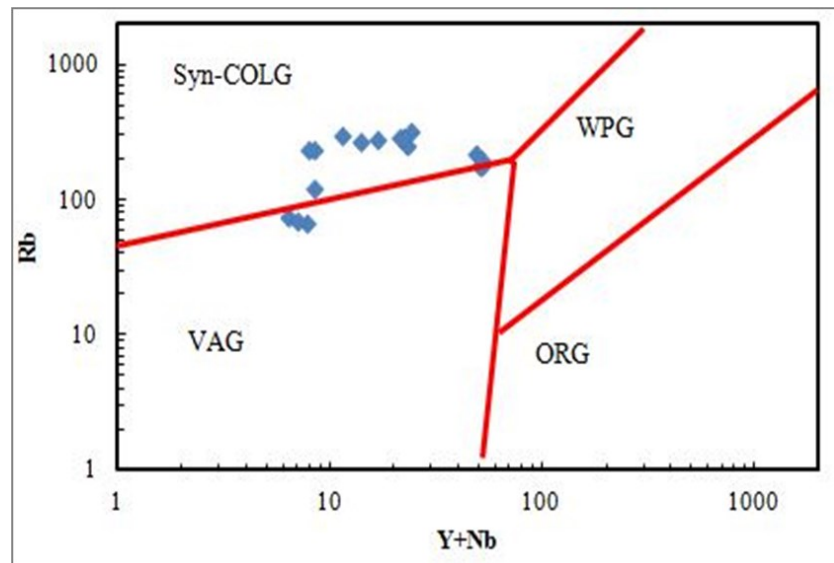

Fig. 11. Tectonic discrimination diagrams of the Pakkanadu alkaline Kamaneri Syenite complex (after Pearce, 1996). that garnet was a residual phase during partial melting in the asthenosphere. The chondrite-normalized REE distribution patterns illustrate that the syenite rock samples are characterized by enrichment in the LREE values ranges from 2.11-12.02 mean value 6.87 and depletion in HREE values range from $0.15-0.49$ mean value 0.34 . The $L R E E / H R E E$ values range from 5.15 16.30, mean value of 9.80 . The Europium (Eu/Eu*)

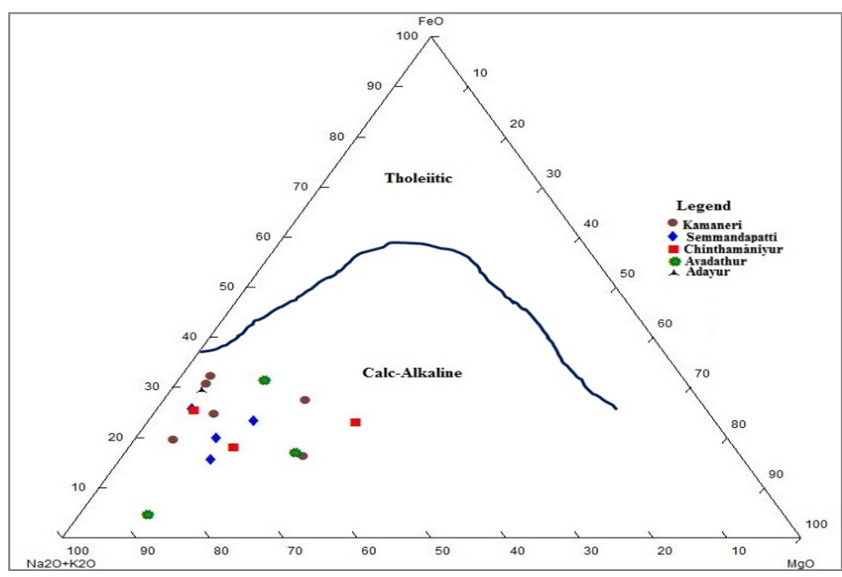

Fig. 8. AFM Trilinear plot (Irvine and Baragar 1971).

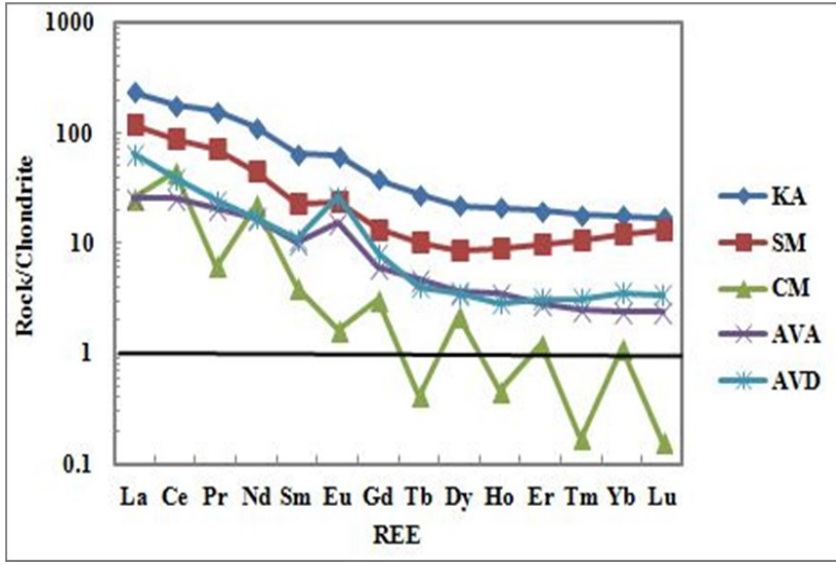

Fig. 10. Chondrite normalized REE patterns of Pakkanadu alkaline Kamaneri Syenite complex (McDonough and Sun, 1995).

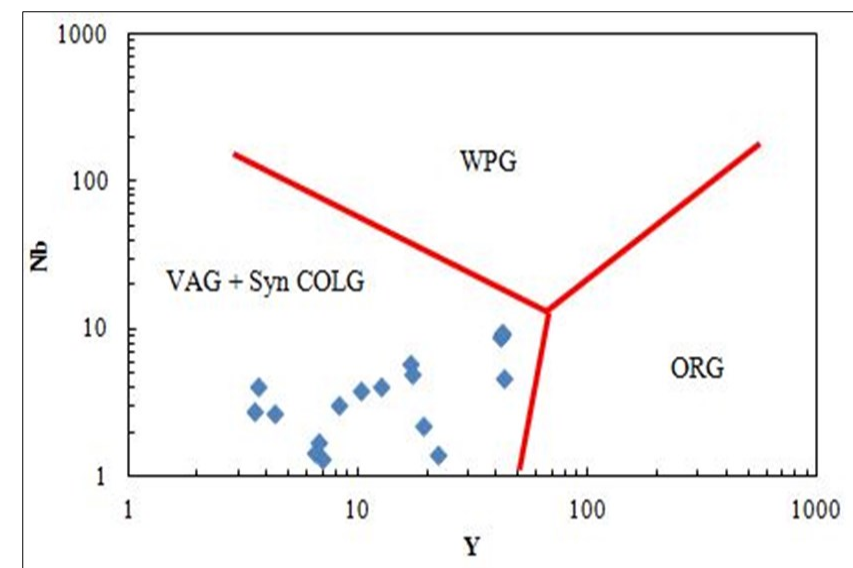

Fig. 12. Nb vs $Y$ plots for tectonic discrimination of Pakkanadu alkaline Kamaneri Syenite complex (after Pearce, 1984). 
anomaly of the study area alkaline syenite rocks had limits of concentration enriched with values ranging from $0.18-0.50$ mean value 0.26 . This can possibly be related to mixing with plagioclase-rich melt. This may be related to the later formation of this intrusive body and strong fractionation during crystallization. From the REE spider diagram, all the REE elements observed in the steep slope pattern, all the samples observed higher concentration of LREE and depleted concentration of HREE. This enriched and depleted pattern indicated that alkaline magma was derived from the mantle sources as also reported by earlier workers (Taylor et al., 1967; Rollinson 1993; Schleicher et al., 1998; Pandit et al., 2002; Upadhyay et al., 2006c; Srinivas et al., 2011; Santosh et al., 2014; Paul et al., 2020).

\section{Tectonic setting}

The emplacement tectonics of various igneous suits are demonstrated by different bivariant and triangular diagrams with the help of major oxides and trace elements (eg. Wood et al., 1979; Floyd and Winchester, 1975; Pearce and Cann 1973; Pearce et al., 1977, 1984; Pearce, 2008; Vrublevskii et al., 2019). In the global context, the syenite magmatism corresponding to Archean age were quite rare compared to Proterozoic, whereas the latter was commonly associated with the continental rift/extensional tectonic settings. The present study used the tectonic discrimination diagrams (Pearce et al., 1984 and 1996) to identify the tectonic emplacement. All the samples were plotted $(\mathrm{Y}+\mathrm{Nb})$ vs $\mathrm{Rb}$ (Fig.11) and $\mathrm{Y}$ vs Nb (Fig.12), most of the samples clustered in the field of syn-COLG + VAG and VAG + syn-COLG, respectively. These samples association of syn-COLG + VAG and VAG + syn-COLG confirm that the Pakkanadu alkaline carbonate complex was mostly derived from fractionate of mantle-derived magmatic sources.

\section{Conclusion}

The field characterization of exposure from Pakkanadu alkaline carbonate complex confirmed the relevant primary and secondary structural properties of syenite alkaline intrusive bodies. The petrography study showed the coarse-grained major and minor minerals such as alkali feldspar, microcline, amphibole, pyroxene, plagioclase, sphene and iron oxides in the samples from PACC. The presence of coarse-grained major and minor minerals in the samples confirmed that all these minerals were formed at deeper depth due to the slow cooling process. Based on the geochemical data, the Pakkanadu alkaline complex highly consisting of alkali elements $\left(\mathrm{Na}_{2} \mathrm{O}+\mathrm{K}_{2} \mathrm{O}\right)$, LILES elements $(\mathrm{Sr}, \mathrm{Ba}$, and $\mathrm{Rb}$ ) and HFSEs ( $\mathrm{Y}, \mathrm{Nb}, \mathrm{Zr}, \mathrm{Ta}, \mathrm{Hf}$, and $\mathrm{Th}$ ). The TAS and AFM diagram inferred that PACC mostly be- 
longs to alkaline nature based on the composition-wise. The Harker variation diagram confirms the syenite intrusion developed by the magmatic differentiation process in PACC region. The higher concentration of trace elements such as enriched LILE ( $\mathrm{Ba}, \mathrm{Sr}$, and $\mathrm{Rb}$ ) elements and High Field Strength Elements (HFSEs) indicate that syenite intrusion is derived from the differentiation of magma mantle source. This enriched and depleted pattern indicates that alkaline magma was derived from mantle sources. The moderate Eu anomaly $\left(\mathrm{Eu} / \mathrm{Eu}^{*}\right)$ suggests that the plagioclase accumulation in the syenite bodies comes from at the crystallization process. The samples association in the plot of synCOLG + VAG and VAG + syn-COLG confirms that the Pakkanadu alkaline carbonate complex is mostly derived from fractionate of mantle-derived magmatic sources.

\section{ACKNOWLEDGEMENTS}

The authors are grateful thanks to Prof. S. Venkateshwaran, Professor and Head, Department of Geology, Periyar University, Salem, for his kind support and encouragement. The authors acknowledge DSTFIST financial supporting for the department of Geology Periyar University. The authors are thankful to Periyar University for providing University Research Fellowship support during the research period. The authors are thankful to the Director, National Geophysical Research Institute (NGRI), Hyderabad, for providing the geochemical analysis support.

\section{Conflict of interest}

The authors declare that they have no conflict of interest.

\section{REFERENCES}

1. Ackerman, L., Magna, T., Rapprich, V., Upadhyay, D., Krátký, O., Čejková, B. \& Hrstka, T. (2017). Contrasting petrogenesis of spatially related carbonatites from Samalpatti and Sevattur, Tamil Nadu, India. Lithos., 284, 257275. doi.org/10.1016/j.lithos.2017.03.029

2. Ashwal, L. D., Patzelt, M., Schmitz, M. D. \& Burke, K (2016). Isotopic evidence for alithospheric origin of alkaline rocks and carbonatites: an example from southern Africa. Canadian Journal of Earth Sciences., 53(11), 1216 -1226. doi.org/10.1139/cjes-2015-0145

3. Burke, K., Ashwal, L. D. \& Webb, S. J. (2003). New way to map old sutures using deformed alkaline rocks and carbonatites. Geology., 31(5), 391-394. doi: 10.1130/00917613(2003)031<0391:NWTMOS>2.0.CO;2

4. Burke, K., Khan, S. D. \& Mart, R. W. (2008). Grenville Province and Monteregian carbonatite and nepheline syenite distribution related to rifting, collision, and plume passage. Geology., 36(12), 983-986. doi:10.1130/G25247A.1

5. Chakrabarty, A., Mitchell, R. H., Ren, M., Saha, P. K., Pal, 
S., Pruseth, K. L. \& Sen, A. K. (2016). Magmatic, hydrothermal and subsolidus evolution of the agpaitic nepheline syenites of the Sushina Hill Complex, India: implications for the metamorphism of peralkaline syenites. Mineralogical Magazine, 80(7), 1161-1193. doi: doi.org/10.1180/ minmag.2016.080.057

6. Das, S., Sanyal, S., Karmakar, S., Sengupta, S. \& Sengupta, P. (2019). Do the deformed alkaline rocks always serve as a marker of continental suture zone? A case study from parts of the Chotanagpur Granite Gneissic complex, India. Journal of Geodynamics., 129, 59-79. doi: 10.1016/j.jog.2018.10.001

7. Fitton, J. G. \& Upton, B. G. (1987). Alkaline igneous rocks: Geological Society of London., Special Publication.

8. Floyd, P. A. \& Winchester, J. A. (1975). Magma type and tectonic setting discrimination using immobile elements. Earth and Planetary Science Letters., 27(2), 211-218. doi.org/10.1016/0012-821X(75)90031-X

9. Gangatharan, P. \& Anbarasu, K. (2020 a). Structural and Textural Characteristic of Syenite Intrusions from Pakkanadu and Pikkili Alkaline Syenite complex Tamilnadu South India. PalArch's Journal of Archaeology of Egypt/ Egyptology., 17(9), 4356-4364.

10. Gangatharan, P. \& Anbarasu, K. (2020 b). Geochemistry Characterization of Alkaline Syenite from Pakkanadu Alkaline Carbonatite Complex, Ultramafic rocks from in Southern Granulite Terrain. PalArch's Journal of Archaeology of Egypt/Egyptology., 17(9), 7736-7746.

11. Gopalakrishnan, K. \& Ganesan, T. M. (1992). A new tectonic model for the evolution of alkaline provinces of northern Tamilnadu. Record Geol. Surv. India., 125(Part-5), 9395.

12. Gopalakrishnan, K. (1993). Supportive field evidence for Dharmapuri suture rift zone, Tamil Nadu. Records of the Geological survey of India., 126 (Part-5), 141-145.

13. Gopalakrishnan, K. (1996). An overview of the southern granulite terrain, India Constraints in the Precambrian assembly of Gondwanaland. Proc.of $9^{\text {th }}$ International Gondwana Symposium, "Gondwana Nine" Oxford and IBH Publishing Co. Pvt. Ltd, New Delhi, vol.2, pp. 10031026.

14. Gopalakrishnan, K., V. Subramanian. \& R. Upendran., (2002). A Tectonic domain based classification of alkaline complexes, alkaline-carbonatite complexes and related rocks within Southern Granulite Terrain, India, its significance from a regional perspective. National Seminar on Alkaline carbonatite magmatic activities; their geological to tectonic settings and associated mineralization to the Indian Panorama. Kakatiya University, Warangal. Andhra Pradesh. Abstract Volume.

15. Hippe, K., Möller, A., von Quadt, A., Peytcheva, I. \& Hammerschmidt, K. (2016). Zircon geochronology of the Koraput alkaline complex: insights from combined geochemical and $\mathrm{U}-\mathrm{Pb}-\mathrm{Hf}$ isotope analyses, and implications for the timing of alkaline magmatism in the Eastern Ghats Belt, India. Gondwana Research., 34, 205-220. doi.org/10.1 016/j.gr.2015.02.021

16. Jeyabalan, M., Udayasankar, S., Thiagarajan, J., Sasikumar, S., Nandhakumar, E., Rajakumaran, M. \& Nagamani, S. (2015). Petrology and geochemistry of lamprophyre rock types of Salem, Dharmapuri, Krishnagiri, and Namakkal districts, Tamil Nadu. Journal of Applied Geochemis- try., 17(2), 213-235.

17. Kerrich, R. \& Wyman, D. A. (1997). Review of developments in trace-element fingerprinting of geodynamic settings and their implications for mineral exploration. Australian Journal of Earth Sciences., 44(4), 465-487. doi.org/10.1080/08120099 708728327

18. Krishnamurthy, P. (2019). Carbonatites of India. Journal of the Geological Society of India., 94(2), 117-138. doi. 10.1007/s12594-019-1281-y

19. Kumar, A., Charan, S. N., Gopalan, K. \& Macdougall, J. D. (1998). A long-lived enriched mantle source for two Proterozoic carbonatite complexes from Tamil Nadu, southern India. Geochimica et Cosmochimica Acta., 62(3), 515523. doi.org/10.1016/S0016-7037(97)00341-4

20. Kumar, K. V., Frost, C. D., Frost, B. R. \& Chamberlain, K. R. (2007). The Chimakurti, Errakonda, and Uppalapadu plutons, Eastern Ghats Belt, India: an unusual association of tholeiitic and alkaline magmatism. Lithos., 97(1-2), 3057. doi 10.1016/j.lithos.2006.11.008

21. Leelanandam, C., Burke, K., Ashwal, L. D. \& Webb, S. J. (2006). Proterozoic mountain building in Peninsular India: an analysis based primarily on alkaline rock distribution. Geological Magazine., 143(2), 195-212. doi.org/10.1017/ S0016756805001664

22. Middlemost, E.A.K. (1994). Naming materials in the magma/igneous rock system. Earth-Science Reviews., 37 (1994) 215-224. doi.org/10.1016/0012-8252(94)90029-9

23. Miyazaki, T., Rajesh, H.M., Ram Mohan, V., Rajasekaran, K.C., Kalaiselvan, A., Rao, A.T. \& Srinivasa Rao, K. (1999). Field study of alkaline plutons in Tamil Nadu and Andhra Pradesh, South India, 1997-1998. Jour. Geosci., Osaka City Univ., vol. 42.

24. Miyazaki, T. \& Santosh, M. (2005). Cooling history of the Puttetti alkali syenite pluton, southern India. Gondwana Research., 8(4), 567-574. doi.org/10.1016/S1342-937X (05)71156-4

25. Miyazaki, T., Kagami, H., Mohan, V. R., Shuto, K. \& Morikiyo, T. (2003). Enriched subcontinental lithospheric mantle in the northern part of the South Indian Granulite Terrain: evidence from Yelagiri and Sevattur syenite plutons, Tamil Nadu, South India. Gondwana Research., 6(4), 585594. doi 10.1016/S1342-937X(05)71009-1

26. Moller, A., Geisler, T., Schleicher, H., Todt, W., Viladkar, S. G. \& Subramanian, V. (2001). Inter-relationship between carbonatite-pyroxenite-syenite complexes of southern India. In Symposium of Carbonatites and Associated Alkaline Rocks and Field Workshop on Carbonatites of Tamil Nadu, Chennai, India (pp. 15-16).

27. Mukhopadhyay, S., Ray, J., Chattopadhyay, B., Sengupta, S., Ghosh, B. \& Mukhopadhyay, S. (2011). Significance of mineral chemistry of syenites and associated rocks of Elagiri Complex, Southern Granulite Terrane of the Indian Shield. Journal of the Geological Society of India., 77(2), 113-129.

28. Natarajan, M., Rao, B. B., Parthasarathy, R., Kumar, A. \& Gopalan, K. (1994). 2.0 GA Old Pyroxenite-Carbonatite Complex of Hogenakal, Tamil-Nadu, South-India. Precambrian Research., doi.org/10.1016/0301-9268(94)90104-X

29. Pandit, M.K., Sial, A.N., Sukumaran, G.B., Ramanathan, S. \& Ferreira, V. P., (1998). Carbon and oxygen isotopic variation in Tamil Nadu carbonatites, South India. Current science., 74(7), pp.620-624. 
30. Pandit, M.K., Sial, A.N., Sukumaran, G.B., Pimentel, M.M., Ramasamy, A.K. and Ferreira, V.P., (2002). Depleted and enriched mantle sources for Paleo-and Neoproterozoic carbonatites of southern India: $\mathrm{Sr}, \mathrm{Nd}, \mathrm{C}-\mathrm{O}$ isotopic and geochemical constraints. Chemical geology., 189(12), pp.69-89.

31. Paul, D., Chandra, J., \& Halder, M. (2020). Proterozoic alkaline rocks and carbonatites of peninsular india: a review. Episodes Journal of International Geoscience., 43 (1), 249-277. doi.org/10.18814/epiiugs/2020/020015

32. Pearce, J. (1996). Sources and settings of granitic rocks Episodes., 19, 120-125.

33. Pearce, J. A., \& Cann, J. R. (1973). Tectonic setting of basic volcanic rocks determined using trace element analyses. Earth and planetary science letters., 19(2), 290-300. doi.org/10.1016/0012-821X(73)90129-5

34. Pearce, J. A., Harris, N. B. \& Tindle, A. G. (1984). Trace element discrimination diagrams for the tectonic interpretation of granitic rocks. Journal of petrology., 25(4), 956983. doi.org/10.1093/petrology/25.4.956

35. Pearce, J. A. (2008). Geochemical fingerprinting of oceanic basalts with applications to ophiolite classification and the search for Archean oceanic crust. Lithos., 100(1-4), 14 -48. doi.org/10.1016/j.lithos.2007.06.016

36. Ranjan, S., Upadhyay, D., Abhinay, K., Pruseth, K. L., \& Nanda, J. K. (2018). Zircon geochronology of deformed alkaline rocks along the Eastern Ghats Belt margin: IndiaAntarctica connection and the Enderbia continent. Precambrian Research., 310, 407-424.

37. Rao, M. S., \& Narayana, B. L. (2002). Geochemistry and petrogenesis of Kunduru Betta calc-alkaline ring complex in the Dharwar Craton, southern India. Gondwana Research., 5(2), 453-465. doi.10.1016/S1342-937X (05) 70735-8

38. Renjith, M. L., Charan, S. N., Subbarao, D. V., Babu, E. V. S. S. K., \& Rajashekhar, V. B. (2014). Grain to outcropscale frozen moments of dynamic magma mixing in the syenite magma chamber, Yelagiri Alkaline Complex, South India. Geoscience Frontiers., 5(6), 801-820. pp.7394. doi.org/10.10 16/j.gsf.2013.08.006

39. Rollinson, H.R. (1993) Using geochemical data: evaluation, presentation, interpretation. Longman Group, London., UK. 352p.

40. Satyanarayanan, M., Balaram, V., Sawant, S. S., Subramanyam, K. S. V., \& Krishna, G. V. (2014). High precision multielement analysis on geological samples by HR-ICP-MS. In 28th ISMAS Symposium Cum Workshop on Mass Spectrometry (pp. 181-184). Indian Society for Mass Spectrometry Mumbai.

41. Santosh, M., lyer, S. S., Vasconcellos, M. B. A., \& Enzweiler, J. (1989). Late Precambrian alkaline plutons in southwest India: geochronologic and rare-earth element constraints on Pan-African magmatism. Lithos., 24(1), 6579. doi.org/10.1016/0024-4937(89)90016-9
42. Schleicher, H., Kramm, U., Pernicka, E., Schidlowski, M., Schmidt, F., Subramanian, V., \& Viladkar, S. G. (1998). Enriched subcontinental upper mantle beneath southern India: evidence from $\mathrm{Pb}, \mathrm{Nd}, \mathrm{Sr}$, and $\mathrm{C}-\mathrm{O}$ isotopic studies on Tamil Nadu carbonatites. Journal of Petrology., 39(10), 1765-1785. doi.org/10.1093/petroj/39.10.1765

43. Schleicher, H. (2019) In-situ Determination of Trace Element and REE Partitioning in a Natural ApatiteCarbonatite Melt System using Synchrotron XRF Microprobe Analysis. Jour. Geol. Soc. India., v.93, pp. 305-312.

44. Srinivas, M., K. Rajendra Prasad, \& K.Sreenu. (2011). Petrology and geochemistry of syenite at Kamaneri area, Salem District, Tamil Nadu. Jour.App. Geochem. v 13. No 1. pp 15 to 26.

45. Taylor Jr, H. P., Frechen, J., \& Degens, E. T. (1967). Oxygen and carbon isotope studies of carbonatites from the Laacher See District, West Germany and the Alnö District, Sweden. Geochimica et Cosmochimica Acta., 31(3), 407430. doi.org/10.1016/0016-7037(67)90051-8

46. Upadhyay, D., \& Raith, M. M. (2006a). Intrusion age, geochemistry and metamorphic conditions of a quartzmonzosyenite intrusion at the craton-Eastern Ghats Belt contact near Jojuru, India. Gondwana Research., 10(3-4), 267-276. doi10.1016/j.gr.2006.02.011

47. Upadhyay, D., \& Raith, M. M. (2006b). Petrogenesis of the Kunavaram alkaline complex and the tectonothermal evolution of the neighboring Eastern Ghats Belt granulites, SE India. Precambrian Research., 150(1-2), 73-94. doi 10.1016/j.precamres.2006.07.006

48. Upadhyay, D., Jahn-Awe, S., Pin, C., Paquette, J. L., \& Braun, I. (2006c). Neoproterozoic alkaline magmatism at Sivamalai, southern India. Gondwana Research., 10(1-2), 156-166. doi org/10.1016/j.gr.2005.11.020

49. Upadhyay, D. (2008). Alkaline magmatism along the southeastern margin of the Indian shield: implications for regional geodynamics and constraints on craton-Eastern Ghats Belt suturing. Precambrian Research., 162(1-2), 59 -69. doi 10.1016/j.precamres.2007.07.012

50. Vrublevskii, V. V., Gertner, I. F., Ernst, R. E., Izokh, A. E., \& Vishnevskii, A. V. (2019). The overmaraat-gol alkaline pluton in northern mongolia: $\mathrm{U}-\mathrm{Pb}$ age and preliminary implications for magma sources and tectonic setting. Minerals., 9(3), 170. doi 10.3390/min9030170

51. Woolley, A. R. (1987). Alkaline rocks and carbonatites of the world: Africa. Geological Society of London.

52. Woolley, A. R., \& Kjarsgaard, B. A. (2008). Paragenetic types of carbonatite as indicated by the diversity and relative abundances of associated silicate rocks: evidence from a global database. The Canadian Mineralogist., 46 (4), 741-752. doi 10.3749/canmin.46.4.741

53. Wood, D. A. (1979) Avariably veined sub-oceanic upper mantle genetic significance for mid-ocean ridge basalts from geochemical evidence. Geology., v. 7, pp. 499-503. DOI: 10.1130/0091-7613(1979)7<499:AVVSUM>2.0.CO;2 